\title{
Modeling the impact of entrepreneurial attitude on self-employment intention among engineering students in Ethiopia
}

Mesfin Mulu Ayalew ${ }^{1 *}$ and Shumet Amare Zeleke²

\author{
*Correspondence: m2mulu@gmail. \\ com \\ 'Department of Statistics, Bahir Dar \\ Institute of Technology, Bahir Dar \\ University, Bahir Dar, Ethiopia \\ Full list of author information is \\ available at the end of the article
}

\begin{abstract}
Entrepreneurship is a worldwide phenomenon with economic growth across the globe that is rendered by the emergence of new and innovative business start-ups. Thus, the main objective of this research was to model the impact of entrepreneurial attitudes on self-employment intention among final year engineering students in Bahir Dar Institute of Technology, Debre Markos University and University of Gondar, Ethiopia, in 2017. To achieve the objective of the study, a survey research approach was employed. Questionnaire and interview were the instruments used, and stratified sampling technique was adopted to select 921 respondents from a population of 4327 final year undergraduate engineering students in 2016/2017 academic session. To analyze the data, descriptive statistics, chi-square test, principal component factor analysis, and binary logistic regression analysis were employed. The descriptive result revealed that about $57.4 \%$ of the students had an intention to be self-employed while $42.6 \%$ do not have an intention. The principal component factor analysis was used to reduce the set of variables by grouping variables with similar characteristics together and generates new variables (factors). These methods help the researchers to transform the number of correlated variables into a smaller number of uncorrelated variables. The logistic regression analysis was performed to investigate the effect of the predictor variables on self-employment intention status of students. The results showed that entrepreneurial education/training and entrepreneurial attitudes significantly predicts students' selfemployment intention. Accordingly, information and opportunity seeking, creativity and problem solving skills, achievement and instrumental readiness, self-confidence and self-esteem, goal setting, entrepreneurship education/training, business-owned family background, prior business experience with family, access to finance/capitals for startup, and networking and professional contacts were found to be significant predictors at $5 \%$ level of significance. These factors had positive relationship with self-employment intention at 5\% level of significance. In the meanwhile, demographic factors (such as age, gender, and marital status) and socio-economic factors (such as parents' occupation, colleagues' business background, means of finance, discouragement by external environment, and clear future business idea) are not significant predictors at $5 \%$ level of significance. The study recommends that the government as well as the universities should design programs that facilitate entrepreneurship to change the mindset, attitude, and intention of those students who do not have knowhow about entrepreneurship as a future career.
\end{abstract}

Keywords: Entrepreneurial attitude, Self-employment intention, Principal component analysis, Binary logit model, Student 


\section{Background}

Entrepreneurship is a worldwide phenomenon with economic growth across the globe that is rendered by the emergence of new and innovative business start-ups. This new and innovative business idea is developed by entrepreneurs. In addition to developing new and innovative business idea, entrepreneurs have also developed certain skills, attitudes, and behavior which enable them to perform their roles in the society (Inegbenobor, 2006). These new businesses play a significant role in job creation, influencing politicians to recognize and support entrepreneurial start-up activity due to its positive contribution to the economy. Therefore, entrepreneurship is a key factor for economic growth (McStay, 2008).

For entrepreneurship, growth drives towards economic growth, public, private, and nongovernmental organizations are taking various measures to promote entrepreneurship in different countries. Universities and colleges have implemented various postgraduate, undergraduate, and diploma courses on small business management and entrepreneurship (Plant and Ren, 2010; Nishantha, 2008). In developing countries, the role of entrepreneurship for development is more important than developed countries as far as the creation of self-employment opportunities and reduction of unemployment situations are concerned (Nishantha, 2008). Currently, the rate of unemployment among high schools and university graduates remains proportionally higher than the rate for less educated workers. Then, providing employment opportunities for all graduates is a crucial issue (Ummah, 2009). One of the ways to solve the problem of unemployment is bringing further graduate entrepreneurship. Graduate entrepreneurship is a process taken by a graduate to start a business in terms of an individual career orientation (Olufunso, 2010). The world needs graduates who are innovative, dynamic, smart, daring, efficient, determined, modern, and employable or, in one word, entrepreneurial.

Higher Learning Institutes in Ethiopia are producing an increasing number of graduates every year. However, the average duration of the unemployment period in urban Ethiopia was found to be more than 1 year (Serneels, 2004). The graduate oversupply has contributed to the imbalance of number of graduates in relation to the job opportunities available in the market. The government has come out with micro-credit loan schemes to help young and inexperienced graduates to start a business. For instance, the government approves 10-billion birr (Ethiopian currency) revolving fund for Ethiopian youth in 2017/2018. The revolving fund was designed to provide financial assistance for youth to help them to employ their capabilities by creating jobs. This fund was administered by the commercial bank of Ethiopia (CBE) and paid to the youth via micro-financial institution for the purpose of job creation. The access to credit facilities helps to encourage the economic growth. Government of Ethiopia have initiated numerous interventions to encourage entrepreneurship; however, enough progress has not been made up to date. This can be attributed to the lack of understanding of the attitudes and perceptions among the youth towards entrepreneurship. These interventions mainly focus on dealing with the most common obstacles such as the financial support and regulation, while ignoring to foster the correct attitude towards entrepreneurship as a career choice.

Students may have different attitude and can react differently on the expected self-employment behavior. Perhaps they can exhibit positive or negative attitude towards 
self-employment depending on their background and other traits. If the students have positive attitudes towards self-employment, it is likely that after graduation, they will start their own business. Conversely, if they form negative attitude, likely they will not become self-employed. In general, individuals desiring more income, more independence, and more net perquisites have high tendency to engage in entrepreneurship (Fitzsimmons and Douglass, 2005). Likewise, an individual with higher tolerance for risk and less aversion to work effort should be expected to be more likely to engage in entrepreneurial behavior (Douglas and Shepherd, 2002).

As mentioned above, entrepreneurship is positively affected by the emergence of new and innovative business start-ups. These new small businesses play a significant role in job creation, influencing politicians to recognize and support entrepreneurial start-up activity due to its positive contribution to economy growth. Studies on the entrepreneurial intention of undergraduates have focused mainly on developed countries. However, developing countries have not been yet focused properly (Olufunso, 2010). Using descriptive research design/framework, different scholars examine the impact/influence of entrepreneurial attitude on self-employment intention. But none of these previous studies model the impact of entrepreneurial attitude of self-employment and examine the extent of the variation in entrepreneurial motivation on self-employment within and between students, departments, and universities. The approaches they stated are suffering from some problems that made them inappropriate to measure the entrepreneurs' attitude and characteristics. Therefore, this research aims to fill the aforementioned gaps of the previous research works not only by using descriptive research designs but also by using inferential research designs. Doing this has the following contributions. Firstly, this study aims to model the impact of entrepreneurial attitude and perception on self-employment intention among final year engineering students in Bahir Dar Institute of Technology, Debre Markos University and University of Gondar in Ethiopia in 2016/2017 academic session. So, this estimated model has a significant contribution for policy makers to predict the probability of students being self-employed in their future career. Secondly, the study quantifies the extent of variation of students on self-employment. Thirdly, it has also a contribution to ascertain whether or not there is a significant difference between the students placed in different departments and universities in their attitudes and perception towards self-employment. Such understanding or finding, in turn, become an input to government officials, educators, potential entrepreneurs, and policy makers to improve the graduate entrepreneurship and hence reduce graduate unemployment.

\section{Literature review}

\section{Theoretical background}

Self-employment intention has been defined in different ways: as the intention to start a new business (Zhao, Hills, and Seibert, 2005), the intention to own a business (Crant, 1996), or the intention to be self-employed (Douglas and Shepherd, 2002). Making graduates more employable is a global challenge, and universities around the world are becoming more entrepreneurial to overcome the challenge. Higher teaching-learning institutions have provided incentives which encourage students to start their own business, informing entrepreneurs when they express a desire to create their own business (Moreno, Castillo, 
and Triguero, 2012). Entrepreneurship education improves motivation towards being entrepreneurial by inspiring students' personal attraction towards entrepreneurship and perceived behavioral control (Dugassa, 2012).

The decision for an individual to become self-employed or to remain as an employee depends on some factors. Many studies pointed out how these factors play an important role in motivating and restraining people to become self-employed. The motivating factors make self-employment to be attractive. For instance, an existing opportunity for profit making may attract young people to start-up their own business. Similarly, low wage or dissatisfied condition of work would make paid employment less attractive. Analyzing factors that influence individuals' decision to become self-employed and why people choose paid employment rather than launch their own business will provide an important guide for policy makers. The reasons why people become self-employed or choose to be employed have been discussed in entrepreneurship literature. Self-employment is being considered synonymous with entrepreneurship. In fact, many studies used self-employment as a proxy for measuring entrepreneurship (Bjuggren, Johansson, and Stenkula, 2012; Rietveld, Hessels, and Zwan, 2014).

Innovation is the tool of entrepreneurship. Innovation is defined as adding something new to an existing product or process. Therefore, people with innovative mindset are more likely to initiate business and sustain it through continuous improvement (Okpara, 2007). In the entrepreneurial development process, entrepreneurs who learn and develop their self-management and self-monitoring skills have more opportunities to enhance entrepreneurial knowledge and experiences (Tseng, 2013). High achievements on creativity and prior entrepreneurial experiences have a direct relationship with entrepreneurial preferences, whereas perception of failure has an indirect influence (Hamidi, Wennberg, and Berglund, 2008). However, diversity of educational background based on department offers plausible explanations on the difference of entrepreneurial perception of university undergraduate students (Wu and Wu, 2008). Students are more likely to formulate the choice of starting their own business, when they successfully feel, recognize, and evaluate their own and others' interest (Zampetakis, Kafetsios, Bouranta, Dewett, and Moustakis, 2009). If the surrounding environment empowers the students and while learning is really based on personal interest, it creates a strong internal motivation (Taatila, 2010). Some scholars pointed out that the higher experience or skill in entrepreneurial, the higher interest for self-employment and the perceived feasibility of self-employment (Davey, Plewa, and Struwig, 2011).

Social factors have an encouraging or impeding effect on the intention of individuals for entrepreneurial career. Family background, education, previous work experience, risk attitude, over-optimism, preference for independence, and the norms and values of a society influence the choice of individual's life careers, i.e., entrepreneurship or salaried employment (Sanditov and Verspagen, 2011). The educational system has a capacity to generate and disseminate knowledge, transform to practices and sources of alternative career choices, and broaden the horizon of individuals in fulfilling economic and social needs. In Africa, for educated people, entrepreneurship is a necessity rather than an opportunity. They established their own business while finding wage employment is highly competitive and full of corruption (Schaumburg-Müller, Jeppesen, and Langevang, 2010).

Different scholars have assessed the attitude of individuals on self-employment using entrepreneur attitude orientation (EAO) model. For instance, Shariff and Saud (2008) conducted a 
research using the EAO model on final year business management undergraduates. Their results show that there is a significant difference between undergraduates minored in entrepreneurship courses and non-entrepreneur undergraduates in terms of self-esteem and personal control, with the mean for the entrepreneur undergraduates group being higher in personal control. Hence, there is no significant difference in terms of innovation and achievement. Zain, Akram, and Ghani (2010) also did a survey among business students and found out that there was a significant relationship between personal traits factor or attitude towards the behavior and the self-employment intention. However, they examine these personal traits or factors in general as the way an individual thinks and behaves without focusing on achievement in business, innovation in business, perceived personal control of business outcomes, and perceived self-esteem in business (EAO model). Moreover, Ismail, Jaffar, and Hooi (2013) conducted a research using entrepreneur attitude orientation (EAO) model to predict the self-employment intentions among the public and private universities' undergraduates in Malaysia. The result of the research shows that personal control, self-esteem, and innovation were found to have significant and positive relationships with self-employment intention. Meanwhile, achievement in business was found to have no significant relationship with self-employment intention.

Nguyen (2017) also studied entrepreneurial intention among international business students in Viet Nam. He used exploratory factor analysis and multiple regressions to examine the responses from 372 final year students. The result of his study confirms that attitude towards entrepreneurship and perceived behavior control is positively related to entrepreneurial intention. On the contrary, subjective norm fails to generate a significant impact on entrepreneurial intention. In related study, other scholars also confirmed that subjective norm, perceived behavioral control, and family business background significantly predicts students' interest in entrepreneurship (Osakede, Lawanson, and Sobowale, 2017). In addition to this, they made at a conclusion that students' interest in entrepreneurship is commonly seen among males than female students. Meanwhile, their findings showed that students' engagement in business activities has no significant effect on academic performance.

The need of student on self-employment can be achieved through effective communication whereby information is captured properly and feedback is provided. Therefore, access to information is also an important element for the intention to establish a new business (Kristiansen and Indarti, 2004). Having access to business information is the availability of information on the environment about establishing a new venture and how to run a business. In addition, availability of finance/capital is also regarded as one of the common obstacle to establish a new business (Kristiansen and Indarti, 2004). Access to finance is the ability of the individuals to find financial support to establish a business since most of the investors and banks are not willing to make investments in new ventures.

There are many research articles on self-employment intentions around the world that focus on attitude towards entrepreneurial behaviors. However, developing countries have not been yet focused properly (Olufunso, 2010). Gemechis (2007) studied a research entitled The Attitude of College Students towards Entrepreneurship on the Case of Addis Ababa University and Rift Valley University College. The findings of his research shows that access to finance for start-up, lack of appropriate education/training, business counseling, and low level of understanding towards entrepreneurship are considered as some of the 
important factors that act as barriers to start a business by the young people. Furthermore, Robson (2015) also studied the determinants of entrepreneurial motivation of undergraduate students in Ethiopian higher learning institutions particularly on Haramaya University. The result of the study shows that the majority of the respondents' family was hired in different companies. However, unlike their family, they would like to become self-employed and plan to operate their own business after graduation. Perceived opportunities of need for independence and higher social position have motivated them to be an entrepreneur. He also pointed out the fact that respondents from business-owned family had high interest in self-employment as compared to respondents from non-business-owned family.

Most studies on entrepreneur attitudes emphasized at a great deal on personality and demographic approaches. The approaches they stated are suffering from some problems that made them inappropriate to measure the entrepreneurs' characteristics. Robinson, Stimpson, Heufner, and Hunt (1991) have developed Entrepreneurial Attitude Orientation (EAO) scale that helps to measure and describes entrepreneur's attitude. They have tested the model and found to be high in validity and reliability.

Due to the needs to encourage universities' undergraduates to explore entrepreneurship, it is essential to understand how to develop and nurture potential entrepreneurs. The research question is whether or not the universities' undergraduates' attitudes towards entrepreneurship have significant relationship with their self-employment intentions. Therefore, this study was conducted to predict the self-employment intention among universities' undergraduates in Ethiopia by adopting the binary logistic regression model.

\section{Conceptual framework and hypothesis development}

Scholars confirm that attitude is the most significant predictors of entrepreneurial and self-employment intention. In contrast, Zhang, Wang, and Owen (2015) confirm a surprise result that attitude fails to generate a significant impact on entrepreneurial intention. It is clear to see that there are differences in the results of the impact of attitude towards self-employment. Hence, based on the review of literature, the following conceptual framework is developed (Fig. 1).

The hypotheses of this study are stated as:

1. H1: higher level of attitudes towards entrepreneurship is associated with higher level of self-employment intention.

2. H2: entrepreneurial education/training is positively related to self-employment intention.

3. H3: demographic factors such as gender, age, and marital status are associated with self-employment intentions.

4. H4: socio-economic factors such as parents' occupation, means of finance, colleague business background, discouragement by external environments, and clear future business idea are positively associated with self-employment intention.

\section{Methods}

\section{Research designs}

This research has been carried out by means of a survey research and referring documents of the concerned offices. Both qualitative and quantitative data are collected and 


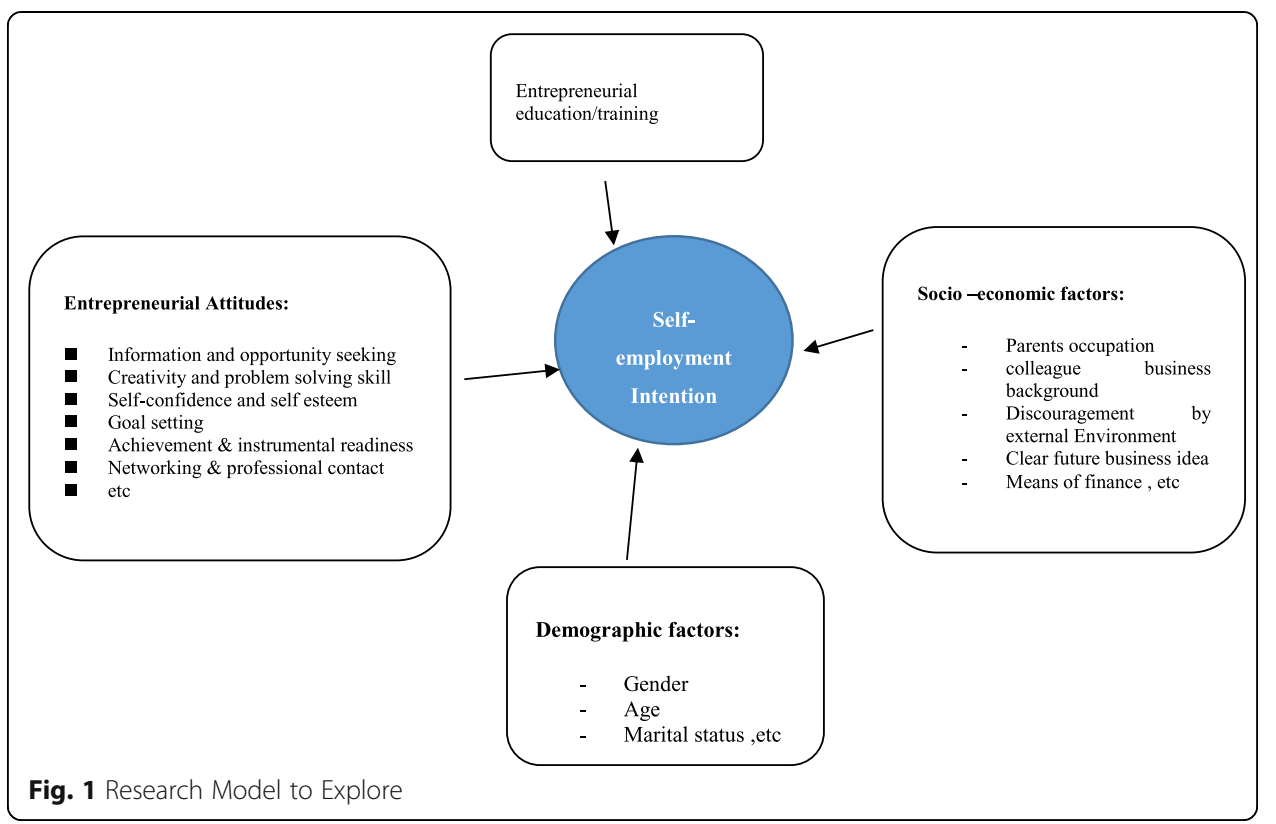

utilized to achieve the stated objectives. Information from the field survey was coded, and estimation was carried out using SPSS 20.

\section{Sample}

The population for this study was final year undergraduate engineering students in Bahir Dar University (BDU), Debre Markos University (DMU) and University of Gondar (UoG) in Ethiopia in 2016/2017 accadamic session. These groups of students were chosen because they were suitable to conduct a research on entrepreneurial intention of students as they were facing important career decisions on completion of their studies, of which entrepreneurship could be one of them. In this research, stratified sampling technique was employed and the required sample size is determined by Yamane (1967) formulae at 5\% level of precision from each university. Concretely, 991 students in UOG, 908 students in DMU and 2428 students in BDU were actively enrolling in 2016/2017 academic session. The study was done by incorporating 907 students from these three universities; 285 from UoG, 278 from DMU, and 344 from BDU.

Furthermore, samples were grouped in terms of their department. With proportionate stratification, the sample size of each department is also determined by Cochran's (1979) formula at 5\% level of precision. Accordingly, 287 Civil Engineering, 129 Electrical Engineering, 118 Mechanical Engineering, 176 Hydraulic and Water Resource Engineering, 14 Industrial Engineering, 77 Chemical Engineering, 30 Computer Engineering, 8 Food Technology and Process Engineering, 14 Architecture and 54 Construction Technology Management Engineering students were selected and participated in the study. The sample size required in this study was 907 students. However, this study involved 921 final year university students who were registered for various engineering degrees. 


\section{Variables of the study}

The dependent (response) variable of this study was self-employment intention of students, and it was measured on a 5-point Likert scaling ranging from strongly disagree to strongly agree, by providing the respondents with 9 statements related to self-employment intentions. For each statement, the respondents were required to circle one number on the scale. For the purpose of this study, the dependent variable classified students as who have self-employment intention and who do not have self-employment intention using standardized factor score (SFS). The SFS values of the response variable, self-employment intention, were obtained using principal component factor analysis. In view of this, the outcome of the $i^{\text {th }}$ student, $Y_{i}$ was measured as a dichotomous variable with possible values coded as 1 and 0 . Therefore, the outcome of the $i^{\text {th }}$ student was formulated as follows.

$$
Y_{i}=\left\{\begin{array}{l}
1, \mathrm{SFS}>0, \text { do have an intention } \\
0, \mathrm{SFS} \leq 0, \text { don't have an intention }
\end{array}\right.
$$

where $Y_{i}$ is self-employment intention status of the $i^{\text {th }}$ student. $I=1,2, \ldots, 921$.

The predictor variables of the study are entrepreneurial attitudes, demographic, and socio-economic characteristics. These variables were chosen from the available similar studies and the available data on the subject. So, factors that are expected to influence the self-employment intention of students are presented in Table 1. One of the factors which was considered as predictor variable in the model was entrepreneurship education/training. It is expected that entrepreneurship education improves motivation to be entrepreneurial by inspiring students' personal attraction towards entrepreneurship and perceived behavioral control. Lack of access to finance and prior experience in business may influence students' engagement in entrepreneurship to establish a business. The researcher expect that students who had access to finance and prior experience are more likely to be self-employed than students who have no any access to finance and experience to establish a business.

The need of students on self-employment can be achieved through effective communication whereby information is captured properly and feedback is provided. Due to this reason, information and opportunity seeking were considered as an predictor variable in the model. It is expected that a student who gather, processe, and use information has more likely to start and engage in entrepreneurship and stay ahead in business. Furthermore, students who have intention in self-employment can see and seize opportunities. They do things by themselves before circumstances force them.

In addition, creativity and problem solving skills were also considered as predictor variables to determine whether or not they have effect on entrepreneurship. It is expected that students with innovative mindset are more likely to initiate business and sustain it through continuous improvement. It means that they find innovative ways to solve problem. They look for new and better ways to do things. In addition, they can develop and maintain business networks and contacts by establishing good working relationship and using deliberate strategies to influence others. The researcher believes that the ability to establish and maintain positive relationship is crucial to the success of the students' business venture. 
Table 1 List of independent variables (covariates)

\begin{tabular}{|c|c|c|c|}
\hline S. no. & Name of variable & Description of predictor variables & Code/level of categories \\
\hline 1 & IOS & $\begin{array}{l}\text { Information and opportunity seeking } \\
\text { factor score }\end{array}$ & None \\
\hline 2 & CPS & $\begin{array}{l}\text { Creativity and problem solving skill } \\
\text { factor score }\end{array}$ & None \\
\hline 3 & AIR & $\begin{array}{l}\text { Achievement and instrumental readiness } \\
\text { factor score }\end{array}$ & None \\
\hline 4 & DEE & $\begin{array}{l}\text { Discouragement by external environment } \\
\text { factor score }\end{array}$ & None \\
\hline 5 & SCSE & $\begin{array}{l}\text { Self-confidence and self-esteem factor } \\
\text { score }\end{array}$ & None \\
\hline 6 & GS & Goal setting factor score & None \\
\hline 7 & $\mathrm{SP}$ & Systematic planning factor score & None \\
\hline 8 & $\mathrm{PO}$ & Parents occupation & $\begin{array}{l}1=\text { agriculture, } 2=\text { gov't employee, } \\
3=\text { private business owned, } 4=\text { others }\end{array}$ \\
\hline 9 & $\mathrm{EE}$ & Entrepreneurship education/training & $1=$ yes, 2 = no \\
\hline 10 & $\mathrm{NE}$ & Networking with entrepreneurs & $1=$ yes, $2=$ no \\
\hline 11 & NERK & $\begin{array}{l}\text { Number of entrepreneurs respondents } \\
\text { know }\end{array}$ & $\begin{array}{l}1=\text { not at all, } 2=\text { less than } 2,3=2 \text { up } \\
\text { to } 4,4=\text { above } 4\end{array}$ \\
\hline 12 & $\mathrm{BOF}$ & Business-owned family & $1=$ yes, 2 = no \\
\hline 13 & PBE & Prior business experience with family & $1=$ yes, 2 = no \\
\hline 14 & $\mathrm{BOC}$ & Business-owned colleague & $1=$ yes, 2 = no \\
\hline 15 & AF & Access to finance/capitals & $1=$ yes, 2 = no \\
\hline 16 & MFSB & Means of finance for starting business & $\begin{array}{l}1=\text { family }, 2=\text { colleague, } 3=\text { micro- } \\
\text { finance, } 4=\text { inheritance, } 5=\text { others }\end{array}$ \\
\hline 17 & IG & Information gathering & $1=$ yes, 2 = no \\
\hline 18 & CFBI & Clear future business ideas & $1=$ yes, 2 = no \\
\hline 19 & RTC & $\begin{array}{l}\text { Risk taking commitment for a career } \\
\text { decision }\end{array}$ & $1=$ yes, $2=$ no \\
\hline
\end{tabular}

Self-confidence and risk taking commitment were also considered as risk factors of self-employment intention. One of the qualities of successful entrepreneur is self-confidence and risk taking commitment. It is expected that a self-confident student has the ability to overcome business problems and succeed in the business activities. Most entrepreneurs start business because they like to be their own boss so that they are responsible for their own decisions. If a person is afraid of uncertainties, then he/she cannot be an entrepreneur. Unlike gamblers, entrepreneurs are not high-risk takers. They calculate their risks before taking action and place themselves in situations involving moderate risk.

Students who have intention about self-employment set meaningful and challenging goals for themselves. To be self-employed, they plan what they do in the future and hit the target by breaking large tasks down into small once and put time limit against them. Moreover, entrepreneurs are not discouraged by difficulties and problems that come up in the business or their personal life. Once they set a goal, they are committed to the goal and will become completely absorbed in it. 


\section{Econometric model specification}

This research was done by using binary logistic regression model. This model allows researchers to predict the $\log$ odds of outcomes of a dependent variable (i.e., self-employment intention) from the set of predictor variables that may be continuous, discrete, categorical, or a mix of any of these (Agresti, 2007; Hilbe, 2009; Hosmer and Lemeshow, 2000). The specification of the model is as follows. Let $Y$ be an $n \times 1$ vector of response variable with $Y_{i}=1$ if the $i^{\text {th }}$ student under study has an intention and $Y_{i}=$ 0 if the $i^{\text {th }}$ student has no intention, $X$ is an $n \times(k+1)$ design matrix of predictor variables, $\beta$ is a $(k+1) \times 1$ vector of parameters.

Given binary outcome variable, self-employment intention of students is examined using the binary logit model. Therefore, the binary logit model used in this study is:

$$
\begin{aligned}
\log (\mathrm{Pi} / 1-\mathrm{pi})=f & (\mathrm{IOS}, \mathrm{CPS}, \mathrm{AIR}, \mathrm{DEE}, \mathrm{SCSE}, \mathrm{GS}, \mathrm{SP}, \mathrm{PO}, \mathrm{EE}, \mathrm{NE}, \mathrm{NERK}, \mathrm{BOF}, \mathrm{PBE}, \\
& \text { BOC, AF, MFSB, IG, CFBI, RTC })
\end{aligned}
$$

For the purpose of estimation, Eq. (2) for modeling self-employment intention is rewritten as:

$$
\text { Logit }(p / 1-p)=\beta_{0}+\beta_{1} \operatorname{IOS}_{\mathrm{i}}+\beta_{2} \mathrm{CPS}_{\mathrm{i}}+\beta_{3} \mathrm{AIR}_{\mathrm{i}}+\ldots \ldots .+\beta_{19} \mathrm{RTC}_{\mathrm{i}}
$$

where

- $\beta^{\prime}=\left(\beta_{0}, \beta_{1} \ldots \beta_{19}\right)=$ vector of coefficient of predictor variables

- $P_{i}=$ probability of $Y_{i}=1$

- $Y_{i}$-whether the $i^{\text {th }}$ student do have self-employment intention or not, i.e., $1=$ do have self-employment intention and $0=$ do not have intention

- $\operatorname{IOS}_{i}=$ information and opportunity seeking factor score of the $i^{\text {th }}$ student

- $\mathrm{CPS}_{i}=$ creativity and problem solving factor score of the $i^{\text {th }}$ student

- $\mathrm{AIR}_{i}=$ achievement and instrumental readiness factor score of the $i^{\text {th }}$ student

- $\mathrm{RTC}_{i}=$ risk taking commitment for career decision of the $i^{\text {th }}$ student. $\mathrm{RTC}_{i}$ measured as a dummy variable with a value of 1 if the student have ability to take risks and 0 otherwise.

\section{Results and discussion}

\section{Description of the data}

As mentioned previously, this study involved 921 final year undergraduate university students who enrolled in various engineering programs. The descriptive result revealed that about $57.4 \%$ of the students have an intention to be self-employed while $42.6 \%$ do not have. From the sample of respondents, $76.7 \%$ were female and $23.3 \%$ were male. In terms of age, $1.1 \%$ were in the age category below 20 years, $77.1 \%$ of the respondents were in the age category between 20 and 24 years, and $21.5 \%$ were in the age category above 24 years. The breakdown of ethnic groups of the respondents was as follows: 69.8\% was Amhara, 12.7\% was Oromo, 7.6\% was Tigrie, and the remaining 9.2\% was others. Based on entrepreneurship training/courses, $55.6 \%$ of the students have taken entrepreneurship and business-related courses/training while $44.4 \%$ did not take any training. The distribution of student's family occupation is also different. That is, $46.9 \%$ of the students came from families in which their livelihood depends upon agriculture, 
$20.8 \%$ of students families are governmental employee, $23.3 \%$ of students families are private business employee, and the remaining are others. Most of the students do not have any exposure to business. $23.4 \%$ of the respondents had tried to start their own business before while $76.8 \%$ of the respondents were not starting their own business. Similarly, $52.8 \%$ of the students came from families who currently run their own business while $47.2 \%$ of the students coming from families who do not run their own business. The respondents also breakdown in terms of whether or not they have capital access; $19.5 \%$ have an access while $79.8 \%$ do not have capital access to run their own business. The majority of students are risk takers. For instance, $81.5 \%$ are risk takers while $18.2 \%$ are not. The majority of students have clear ideas what kind of business they want to do in the future (69.1\%) while $30.9 \%$ of the students do not have clear idea to run business.

\section{Factor analysis and reliability analysis}

Since the research data contains many correlated variables, exploratory factor analysis was performed separately on the dimensions of students' self-employment intention (dependent variable) and entrepreneurial attitudes (predictor variables). The extraction method used for exploring factors is principal component analysis (PCA) with rotated component matrix using varimax normalization and only take components when eigenvalues are greater than one. This method helps to reduce the number of variables by grouping variables with similar characteristics together and generates new variables (factors) that are uncorrelated with one another and capable of explained the observed variance in the large number of variables (Meyers, Gamst and Guarino, 2006). Finally, these reduced factors are employed for regression analysis.

Firstly, factor analysis was conducted to confirm the validity of self-employment intention. Self-employment intention of students has been measured with 9 statements with 5 Likert-scale. The statements used to measure self-employment intention of students are listed in the Appendix (see this in section "Literature review" of the questionnaire from Q1-Q9).

To apply PCA method, firstly it is mandatory to check the adequacy of the data. It was checked by The Kaiser-Mayer-Olkin (KMO) and Bartlett's Test of Sphericity statistics. The Kaiser-Mayer-Olkin (KMO) measure of sampling adequacy for the dimension of self-employment intention was 0.885 which indicates that the sample is adequate. A $\mathrm{KMO}$ value greater or equal to 0.70 is considered as adequate (Meyers, Gamst, and Guarino, 2006). The Bartlett's Test of Sphericity (ch-sq $=2295.047)$ was also significant at $5 \%$ level. This value of KMO and Bartlett's Test of Sphericity statistic shows us the appropriateness to apply exploratory factor analysis for 9 questions (statements) of dependent variable.

After checking the validity and adequacy of the sample, the next step is to conduct exploratory factor analysis. Table 2 shows the actual factors which were extracted. The section labeled "Extraction Sums of Squared Loadings" shows that only those factors that met cutoff criterion (extraction method). For the purpose of the hypothesis testing, only statements with eigenvalue greater than 1 will be taken in the final analysis. In this case, there was one statement with eigenvalues greater than 1 . Therefore, of the nine statements, only one statement is taken/retained in the final analysis. The "\% of 
Table 2 Total variance explained

\begin{tabular}{|c|c|c|c|c|c|c|}
\hline \multirow[t]{2}{*}{ Statements } & \multicolumn{3}{|c|}{ Initial eigenvalues } & \multicolumn{3}{|c|}{ Extraction sums of squared loadings } \\
\hline & Total & $\%$ of variance & Cumulative $\%$ & Total & $\%$ of variance & Cumulative $\%$ \\
\hline 1 & 3.920 & 43.556 & 43.556 & 3.920 & 43.556 & 43.556 \\
\hline 2 & .925 & 10.277 & 53.833 & & & \\
\hline 3: & $.809:$ & 8.984: & 62.817: & & & \\
\hline 9 & .408 & 4.530 & 100.000 & & & \\
\hline
\end{tabular}

Extraction method: principal component analysis

variance" column tells us how much the total variability (in all of the variables together) can be accounted for by each of these summary scales or factors. Statement 1 accounts for $43.56 \%$ of the variability in all nine statements and so on.

Secondly, factor analysis is also conducted to confirm the validity and adequacy of predictor variables (entrepreneurial attitude related variables). The Kaiser-Mayer-Olkin measure of sampling adequacy was 0.947 and The Bartlett's Test of Sphericity (app chi-square $=13,322.545)$ was significant at $5 \%$ level. This indicates that the sample is adequate and means that it is appropriate to apply exploratory factor analysis for 41 questions (statements) of entrepreneurial attitude-related statements.

Table 3 intends to show that actual factors that were extracted. The section labeled "Rotation Sums of Squared Loadings" shows only factors that met cutoff criterion (extraction method). In this case, there are seven statements with eigenvalues greater than 1. Of the 41 statements (see this in section "Material and methodology" of the questionnaire from Q1-Q41 in the Appendix), only seven statements were taken or retained in the final analysis. The "\% of variance" column tells us how much of the total variability (in all of the variables together) can be accounted for by each of these summary scales or factors. Factor 1 accounts for $27.29 \%$ of the variability in all 41 statements, factor 2 accounts for $8.04 \%$ of the variability in all 41 statements and so on.

In Table 4, we report to show rotated component matrix using the varimax normalization, which gathers the factor scores/loadings for each variable on which we establish the interpretation of factors resulting from the analysis. We went across each row and highlighted the factor that each variable loaded most strongly on. Therefore,

Table 3 Total variance explained for the forty-one statements

\begin{tabular}{|c|c|c|c|c|c|c|c|c|c|}
\hline \multirow[t]{2}{*}{ Statement } & \multicolumn{3}{|c|}{ Initial eigenvalues } & \multicolumn{3}{|c|}{$\begin{array}{l}\text { Extraction sums of } \\
\text { squared loadings }\end{array}$} & \multicolumn{3}{|c|}{$\begin{array}{l}\text { Rotation sums of } \\
\text { squared loadings }\end{array}$} \\
\hline & Total & $\begin{array}{l}\% \text { of } \\
\text { variance }\end{array}$ & $\begin{array}{l}\text { Cumulative } \\
\%\end{array}$ & Total & $\begin{array}{l}\% \text { of } \\
\text { variance }\end{array}$ & $\begin{array}{l}\text { Cumulative } \\
\%\end{array}$ & Total & $\begin{array}{l}\% \text { of } \\
\text { variance }\end{array}$ & $\begin{array}{l}\text { Cumulative } \\
\%\end{array}$ \\
\hline 1 & 11.190 & 27.294 & 27.294 & 11.190 & 27.294 & 27.294 & 7.790 & 19.000 & 19.000 \\
\hline 2 & 3.297 & 8.040 & 35.334 & 3.297 & 8.040 & 35.334 & 4.167 & 10.164 & 29.165 \\
\hline 3 & 2.123 & 5.177 & 40.511 & 2.123 & 5.177 & 40.511 & 2.735 & 6.670 & 35.834 \\
\hline 4 & 1.480 & 3.609 & 44.120 & 1.480 & 3.609 & 44.120 & 2.346 & 5.721 & 41.555 \\
\hline 5 & 1.164 & 2.839 & 46.960 & 1.164 & 2.839 & 46.960 & 1.549 & 3.777 & 45.332 \\
\hline 6 & 1.105 & 2.696 & 49.656 & 1.105 & 2.696 & 49.656 & 1.466 & 3.575 & 48.908 \\
\hline 7 & 1.036 & 2.528 & 52.184 & 1.036 & 2.528 & 52.184 & 1.343 & 3.276 & 52.184 \\
\hline 8: & .961 & 2.343 & 54.527 & & & & & & \\
\hline 41 & .303 & .738 & 100.000 & & & & & & \\
\hline
\end{tabular}


Table 4 Rotated component matrix

\begin{tabular}{|c|c|c|c|c|c|c|c|}
\hline \multirow[t]{2}{*}{ Statements } & \multicolumn{7}{|c|}{ Component } \\
\hline & $\begin{array}{l}\text { Factor } \\
1\end{array}$ & $\begin{array}{l}\text { Factor } \\
2\end{array}$ & \begin{tabular}{|l} 
Factor \\
3
\end{tabular} & $\begin{array}{l}\text { Factor } \\
4\end{array}$ & \begin{tabular}{|l|} 
Factor \\
5
\end{tabular} & \begin{tabular}{|l|} 
Factor \\
6
\end{tabular} & $\begin{array}{l}\text { Factor } \\
7\end{array}$ \\
\hline To start a business project, I will gather information beforehand & .748 & .062 & .092 & -.073 & .010 & -.005 & .027 \\
\hline If I am involved in any business project, I believe I can perform very well & .721 & .082 & .254 & -.048 & .006 & .042 & -.209 \\
\hline I like to think about the future & .702 & .087 & .170 & -.033 & -.029 & -.094 & -.067 \\
\hline To succeed in business it is important to work with others & .628 & .087 & .186 & -.079 & .202 & .140 & .002 \\
\hline At the time of work, I will seek the advice of people & .628 & .050 & .053 & .046 & .151 & .124 & .197 \\
\hline I think that there is always a better way of doing things & .614 & .146 & .089 & .006 & .194 & .079 & -.131 \\
\hline If one way of solving problem doesn't work ,''ll look for another approach & .601 & .083 & .026 & .090 & .149 & .070 & .140 \\
\hline I like challenges and new opportunities & .594 & .140 & .162 & .096 & .055 & .079 & .068 \\
\hline I feel confident that I can succeed in any business activities & .591 & .131 & .122 & .294 & -.028 & -.022 & -.163 \\
\hline If I know well what I want to do, I will achieve it well & .583 & .143 & .198 & .119 & .105 & .023 & .137 \\
\hline I will look for a new business that no one has done & .570 & .063 & .082 & .209 & .119 & .031 & .121 \\
\hline I try to take in to consideration all the problems that may crop up & .565 & .160 & .210 & .162 & .027 & .055 & .389 \\
\hline I will do what I have to do before circumstances force me to do & .561 & .141 & .199 & .202 & .114 & .089 & .211 \\
\hline $\begin{array}{l}\text { When I deal with successful businessperson, I am being inspired to start } \\
\text { business }\end{array}$ & .560 & .107 & .313 & -.013 & .156 & .138 & -.090 \\
\hline I deal with problems when they arise, rather than wasting time & .546 & .076 & .026 & .132 & -.006 & .162 & .301 \\
\hline I can persuade people to change their opinion through discussion & .531 & .138 & .219 & .122 & .089 & .029 & .165 \\
\hline Before doing something, I carefully weight the chances of success\& failure & .515 & .137 & .153 & .165 & .062 & -.009 & .507 \\
\hline When I am doing something difficult, I feel confident that I will succeed & .468 & .076 & .141 & .419 & -.043 & -.126 & -.021 \\
\hline I prefer doing things that I do easily and with which I feel comfort & .426 & .065 & .144 & .218 & .329 & .082 & .134 \\
\hline I am mentally mature to start my own business & .379 & .087 & .363 & .228 & -.010 & .179 & -.324 \\
\hline I will engaged in the development of new products and services & .047 & .802 & .060 & .057 & -.021 & .021 & .074 \\
\hline I prefer to implement new ideas than existing ones & .122 & .787 & .076 & .008 & -.049 & .016 & .129 \\
\hline I have a capacity to create new ideas & .132 & .781 & .040 & .099 & .036 & .054 & -.031 \\
\hline I will make networking \& professional contacts before starting business & .103 & .777 & .046 & .037 & -.044 & .094 & .087 \\
\hline I have strong leadership and communication skills & .092 & .764 & .110 & -.048 & .015 & -.006 & .087 \\
\hline I will make every efforts to solve problem & .162 & .702 & .125 & .020 & .133 & .015 & -.080 \\
\hline I have a satisfactory level of opportunity recognition & .208 & .465 & .056 & .079 & .194 & -.003 & -.142 \\
\hline I will do very well in difficult tasks relating to my job & .314 & .124 & .658 & -.030 & .136 & -.007 & .255 \\
\hline I have an access to capital to start to be an entrepreneur & .204 & .230 & .640 & .223 & -.042 & .148 & -.037 \\
\hline I have good social relation with others to be an entrepreneur & .323 & .122 & .631 & .154 & -.108 & .063 & -.122 \\
\hline I will try hard to improve on past work performance & .354 & .077 & .589 & -.056 & .229 & .033 & .209 \\
\hline I will accept additional responsibilities in job assigned to me & .386 & .025 & .503 & -.032 & .218 & .020 & .112 \\
\hline I think it is a waste of time to worry about what I should do with my life & .060 & -.015 & -.070 & .693 & .028 & .162 & .094 \\
\hline I will change my way of thinking if others oppose my point of view & .095 & .078 & .139 & .654 & .163 & -.070 & -.030 \\
\hline I think it is a waste of time to worry about what I should do with my life & .125 & .031 & .026 & 642 & .113 & .161 & .126 \\
\hline It bothers me when business activities do not go in the right manner & -.172 & .115 & .297 & .399 & .059 & .382 & -.163 \\
\hline I shall feel uncomfortable if I am not sure of the goal of my future business & .162 & .098 & .111 & .077 & .748 & .130 & .027 \\
\hline I feel confident that I can succeed in any business activities. & .288 & -.006 & .020 & .276 & .641 & -.027 & .038 \\
\hline I would rather found a company than to be a manager of an existing one & .181 & .144 & .034 & .063 & .101 & .724 & -.016 \\
\hline I can only make a lot of money if I am self-employed & .120 & -.034 & .094 & .118 & .010 & .699 & .084 \\
\hline I will plan a large task by breaking it down into smaller activities & .359 & .147 & .231 & .292 & .134 & .128 & .433 \\
\hline
\end{tabular}

based on factor loadings, all the 41 statements (see in Table 4) are reduced/grouped into seven factors and the following names were given for each factor with relating to the statements.

- The first 20 statements grouped or loaded strongly on factor 1 , which is taken as "Information and Opportunity Seeking" in the final regression model.

- In the same way, by observing the factor loadings, the next seven statements grouped or strongly loaded on factor 2 and taken as "Creativity and Problem Solving Skills" in the model.

- The next five statements were grouped or loaded on factor 3, and we call "Need of Achievement and Instrumental Readiness."

- Four statements were loaded on factor 4, and we call them "Discouragement by External Enviroment."

- The next two statements were grouped on factor 5 and factor 6 and taken as "Selfconfidence and Self-esteem" and "Goal setting," respectively.

- Finally, one statement was loaded on factor 7 and considered as "Systematic Planning." 
Finally, these seven factors (with addition to other significant variables listed in Table 5) are used as the predictors of the self-employment intention of the students in the final analysis.

The reliability of the data was checked by using Chronbanch's alpha statistics. The value of this statistic is 0.917 which is greater than the minimum acceptable value of 0.70 . This indicates that the data is reliable and can be concluded that the items measuring entrepreneurial attitudes and self-employment intention were assessed to be reliable.

\section{Test of association between variables}

Before we go to model the self-employment intention of students, first we assessed the association between self-employment intention with student's demographic and socio-economic characteristics. Using chi-square test, any variable having a significant relationship from self-employment intention is considered as a candidate for logistic regression analysis. The results are summarized as follows.

In Table 5, we assessed the association between self-employment intention with demographic and socio-economic characteristics using chi-square test. The result shows that self-employment intention has association with entrepreneurship education/training, prior business experience with family, access to finance/capital, business-owned family, clear future business ideas, information gathering, business-owned colleague/relatives, risk taking commitment, means of finance, parents' occupation (profession), number of entrepreneurs in which students know, and networking with entrepreneurs. Meanwhile, gender, age, educational background of parents, place of birth, marital status, place of study, ethnicity, economic status of the household, religion, and field of study do not have any significant association with self-employment intention at $5 \%$ level of significance. For instance, students placed on different department (field of study) and university (place of study) do not have significant variation on self-employment intention. The chi-square test in Table 5 also shows that males do not have higher tendency to engage in self-employment activities than females and vice versa. It means that there is no significant difference between male and female on self-employment intention. In conclusion, H3: demographic factors such as gender, age, and marital status are associated with self-employment intention is not supported. Similarly, H4: socio-economic factors such as parents' occupation, colleagues business background, means of finance, discouragement by external environment, and clear future business idea are positively associated with self-employment intention is not supported.

\section{Parameter estimation of the binary logistic model}

Firstly, we fit an empty model without any predictor variables (covariates) and we obtain the initial $\log$-likelihood $(-2 \mathrm{LL})$. The initial $-2 \mathrm{LL}$ value is 1182.137 at step 0 , before any variables have been added to the model. Secondly, we include all the covariates (the newly created variables in Table 4 and the significant variables in Table 5) into the model and we identify whether or not the addition of these covariates decreases the log-likelihood. The SPSS provides the following results. 
Table 5 Test of association $B / n$ self-employment intention with demographic and socio-economic characteristics of respondents

\begin{tabular}{|c|c|c|c|c|}
\hline S. no. & Characteristics & Pearson $X^{2}-$-value & $d f$ & $\begin{array}{l}\text { Asymp. sig } \\
\text { (two-sided) }\end{array}$ \\
\hline 1. & Clear future business ideas & 14.814 & 1 & $0.000^{*}$ \\
\hline 2. & Information gathering & 25.826 & 1 & $0.000^{*}$ \\
\hline 3. & Business-owned colleague/relatives & 10.153 & 1 & $0.001^{*}$ \\
\hline 4. & Risk taking commitment & 11.448 & 1 & $0.001^{*}$ \\
\hline 5. & Means of finance & 17.231 & 3 & $0.001^{*}$ \\
\hline 6. & Parents occupation & 10.271 & 3 & $0.016^{*}$ \\
\hline 7. & No. of entrepreneurs in which students know & 9.971 & 3 & $0.019^{*}$ \\
\hline 8. & Networking with entrepreneurs & 14.580 & 1 & $0.000^{*}$ \\
\hline 9. & Prior business experience with family & 14.432 & 1 & $0.000^{*}$ \\
\hline 10. & Parents education & 6.773 & 3 & 0.080 \\
\hline 11. & Place of study & 9.005 & 2 & 0.110 \\
\hline 12. & Entrepreneurship education/training & 12.556 & 1 & $0.001^{*}$ \\
\hline 13. & Place of birth & 1.924 & 1 & 0.165 \\
\hline 14. & Business-owned family & 15.68 & 1 & $0.000^{*}$ \\
\hline 15. & Age & 3.415 & 2 & 0.181 \\
\hline 16. & Marital status & 3.348 & 2 & 0.187 \\
\hline 17. & Ethnicity & 9.557 & 3 & 0.230 \\
\hline 18. & Access to finance/capitals & 11.405 & 1 & $0.001^{*}$ \\
\hline 19. & Economic status of household & 1.535 & 2 & 0.464 \\
\hline 20. & Field of study & 2.226 & 3 & 0.527 \\
\hline 21. & Religion & 2.048 & 3 & 0.562 \\
\hline 22. & Gender & 0.306 & 1 & 0.580 \\
\hline
\end{tabular}

*Significant at 5\%

Table 6 shows us the Omnibus test of model coefficients. The Omnibus Tests of Model Coefficients is used to check that the new model (with all explanatory variables included) is an improvement over the baseline model. It uses chi-square tests to see if there is a significant difference between the log-likelihoods (specifically the -2LLs) of the baseline model and the new model. Here, the chi-square is highly significant (chi-square $=371.302, d f=25, p<.000$ ). So, our new model is significantly better. This indicated that the overall model provides a statistically significant relationship between self-employment intention and entrepreneurial attitude-related variables.

The model summary (in Table 7) also provides the $-2 \mathrm{LL}$ and pseudo- $R^{2}$ values for the full model. The $-2 \mathrm{LL}$ value for this model (810.835) is what was compared to the - 2LL for the previous null model in the "omnibus test of model coefficients" which

Table 6 Omnibus tests of model coefficients

\begin{tabular}{lllll}
\hline & & Chi-square & df & Sig. \\
\hline Step 1 & Step & 371.302 & 25 & .000 \\
& Block & 371.302 & 25 & .000 \\
& Model & 371.302 & 25 & .000 \\
\hline
\end{tabular}


Table 7 Model summary

\begin{tabular}{llll}
\hline Step & -2 log-likelihood & Cox and snell $R^{2}$ & Nagelkerke $R^{2}$ \\
\hline 1 & $810.835^{a}$ & .349 & .469 \\
\hline a &
\end{tabular}

${ }^{a}$ Estimation terminated at iteration number 5 because parameter estimates were changed by less than .001

told us there was a significant decrease in the $-2 L L$, i.e., that our new model (with predictor variables) is significantly better fit than the null model. The $R^{2}$ values tell us approximately how much variation in the outcome is explained by the model. We prefer to use the Nagelkerke's $R^{2}$ which suggests that the model explains roughly $46.9 \%$ of the variation in the outcome. The overall significance of the model was also checked by using Hosmer-Lemeshow (HL) goodness fit statistic. The HL statistic (chi-square $=7.545$ ) was insignificant at $5 \%$ level (i.e., $P$ value $=0.475$ ). This indicates that the overall model provides a statistical significant relationship between entrepreneurial attitudes and self-employment intention.

This study found evidence that entrepreneurial attitudes have significant influence on students' self-employment intention. The results conformed to the literatures that entrepreneurial attitude do have relationship with self-employment intentions. Based on Table 8, this research arrives at the following conclusions.

Entrepreneurship education improves motivation towards being entrepreneurial by inspiring students' personal attraction towards entrepreneurship and perceived behavioral control (Dugassa, 2012; Gemechis, 2007; Sanditov and Verspagen, 2011). This is consistent with our findings. The result of this research indicates that students who took entrepreneurship education/training were $5.493(\mathrm{OR}=5.493)$ times higher than those students who did not take entrepreneurship education/trainings while controlling other variables. In conclusion, H2: entrepreneurial education/training is positively related to self-employment intention is supported.

Generally, students who came from business-owned family are more likely to be self-employed compared to students who came from non-business-owned families. But students who have business-owned colleagues are not significantly different from students who do not have business-owned colleagues. Table 8 tells us that students who came from business-owned families were $25.4 \%(\mathrm{OR}=1.254)$ more likely to be self-employed compared to students who came from non-business-owned families. The reason might be that they may have prior business experience from families. The experience gained from their family member may influence the students' engagement in entrepreneurship. This is in agreement with the findings in other studies (Fitzsimmons and Douglass, 2005; Dohse and Walter, 2012; Sanditov and Verspagen, 2011; Robson, 2015). Similarly, the odd of self-employment intention of students who have prior business experience from their family was $45.1 \%$ more likely to be self-employed than students who have no any prior business experience from their family controlling other variables.

The odd of self-employment intention of students who have access to finance/ capital was about $2.11(\mathrm{OR}=2.11)$ times higher than the odd of self-employment intention of students who do not have access to capitals controlling for other variables in the model. Meanwhile, profession of parents is found to be insignificant for self-employment intention. Intention of students in which their family 
Table 8 Variables in the equation

\begin{tabular}{|c|c|c|c|c|c|c|c|c|c|}
\hline \multirow{2}{*}{\multicolumn{2}{|c|}{ Variables }} & \multirow[t]{2}{*}{$B$} & \multirow[t]{2}{*}{ S. E. } & \multirow[t]{2}{*}{ Wald } & \multirow[t]{2}{*}{$d f$} & \multirow[t]{2}{*}{ Sig. } & \multirow{2}{*}{$\begin{array}{l}\text { Exp } \\
(B)\end{array}$} & \multicolumn{2}{|c|}{$95 \% \mathrm{Cl}$ for $\operatorname{EXP}(B)$} \\
\hline & & & & & & & & Lower & Upper \\
\hline \multicolumn{2}{|l|}{$\mathrm{IOS}$} & 1.338 & .120 & 124.665 & 1 & $.000^{*}$ & 3.813 & 3.015 & 4.823 \\
\hline \multicolumn{2}{|l|}{ CPS } & .351 & .095 & 13.767 & 1 & $.000^{*}$ & 1.421 & 1.180 & 1.710 \\
\hline \multicolumn{2}{|l|}{ AIR } & .842 & .098 & 73.207 & 1 & $.000^{*}$ & 2.320 & 1.913 & 2.813 \\
\hline \multicolumn{2}{|l|}{ DEE } & .062 & .096 & .424 & 1 & .515 & 1.064 & .882 & 1.284 \\
\hline \multicolumn{2}{|l|}{ SCSE } & .416 & .093 & 19.956 & 1 & $.000^{*}$ & 1.516 & 1.263 & 1.819 \\
\hline \multicolumn{2}{|l|}{ GS } & .588 & .094 & 39.172 & 1 & $.000^{*}$ & 1.800 & 1.497 & 2.163 \\
\hline \multicolumn{2}{|l|}{ SP } & .030 & .087 & .119 & 1 & .730 & 1.031 & .868 & 1.223 \\
\hline \multicolumn{2}{|l|}{$\mathrm{PO}$} & & & 1.782 & 3 & .619 & & & \\
\hline \multicolumn{2}{|c|}{ Agriculture } & -.258 & .332 & .603 & 1 & .438 & .773 & .403 & 1.482 \\
\hline \multicolumn{2}{|c|}{ Gove'tal employee } & -.013 & .365 & .001 & 1 & .971 & .987 & .482 & 2.020 \\
\hline \multicolumn{2}{|c|}{ Private business owned } & -.007 & .365 & .000 & 1 & .984 & .993 & .486 & 2.030 \\
\hline \multicolumn{2}{|c|}{ Other (ref) } & - & - & - & - & - & - & - & - \\
\hline \multirow[t]{2}{*}{$\mathrm{EE}$} & Yes & 1.703 & .172 & 97.64 & 1 & $.000^{*}$ & 5.493 & 3.918 & 7.700 \\
\hline & No (ref.) & - & - & - & - & - & - & - & - \\
\hline \multirow[t]{2}{*}{ NE } & Yes & .408 & .049 & 68.44 & 1 & $.000^{*}$ & 1.503 & 1.365 & 1.655 \\
\hline & No (ref.) & - & - & - & - & - & - & - & - \\
\hline \multicolumn{2}{|c|}{ NERK } & & & 5.136 & 3 & .162 & & & \\
\hline & & -.340 & .268 & 1.610 & 1 & .204 & .712 & .421 & 1.203 \\
\hline & & .175 & .298 & .345 & 1 & .557 & 1.191 & .664 & 2.136 \\
\hline & & -.291 & .273 & 1.141 & 1 & .285 & .747 & .438 & 1.275 \\
\hline & & - & - & - & - & - & - & - & - \\
\hline $\mathrm{BOF}$ & Yes & .226 & .056 & 16.479 & 1 & $.000^{*}$ & 1.254 & 1.124 & 1.399 \\
\hline & No (ref.) & - & - & - & - & - & - & - & - \\
\hline PBE & Yes & .372 & .060 & 37.919 & 1 & $.000^{*}$ & 1.451 & 1.289 & 1.634 \\
\hline & No (ref.) & - & - & - & - & - & - & - & - \\
\hline $\mathrm{BOC}$ & Yes & .043 & .200 & .046 & 1 & .831 & 1.044 & .705 & 1.545 \\
\hline & No (ref.) & - & - & - & - & - & - & - & - \\
\hline $\mathrm{AF}$ & Yes & .0 .747 & .055 & 186.432 & 1 & $.000^{*}$ & 2.110 & 1.896 & 2.349 \\
\hline & No (ref.) & - & - & - & - & - & - & - & - \\
\hline MFSB & & & & 10.992 & 3 & .612 & & & \\
\hline Far & & 1.200 & .414 & 8.406 & 1 & .004 & 3.322 & 1.475 & 7.478 \\
\hline & & -.258 & .923 & .078 & 1 & .780 & .773 & .127 & 4.718 \\
\hline Mic & & .805 & .309 & 6.793 & 1 & .009 & 2.237 & 1.221 & 4.100 \\
\hline & & - & - & - & - & - & - & - & - \\
\hline IG & Yes & .461 & .237 & 3.778 & 1 & .052 & 1.586 & .996 & 2.526 \\
\hline & No (ref.) & - & - & - & - & - & - & - & - \\
\hline CFBI & Yes & .336 & .199 & 2.847 & 1 & .092 & 1.399 & .947 & 2.066 \\
\hline & No (ref.) & - & - & - & - & - & - & - & - \\
\hline RTC & Yes & .212 & .237 & .797 & 1 & .372 & 1.236 & .776 & 1.967 \\
\hline & No (ref.) & - & - & - & - & - & - & - & - \\
\hline Const & & -1.191 & .563 & 4.474 & 1 & .034 & .304 & & \\
\hline
\end{tabular}

ref. reference category

*Significant at 5\% level of significance 
livelihood is agriculture is not significantly different from governmental employee families. Similarly, students who came from government employee family are not significantly different students came from private business-owned family in their self-employment intention, etc.

The need of student on self-employment can be achieved through effective communication whereby information is captured properly and feedback is provided. This research comes up with the evidence that there is a significant difference in self-employment intention status of students between information and opportunity seekers and non-seekers. The seekers have high intention $(\mathrm{OR}=3.813)$ to be self-employed than non-seekers. Other researchers also pointed out that students who seek information and opportunity are more likely to be self-employed than non-seekers (Hamidi et al., 2008). As expected, students who gather, process, and use information are more likely to start and engage in entrepreneurship and stay ahead in business. Students who have intention in self-employment can quickly see and seize opportunities. They do things before circumstances force them to do. If a student has an intention to be self-employed, then he/she always wants to learn things that will help him/her to grow business. On the other hand, there is no significant difference between students who know a number of entrepreneurs and students who do not know any entrepreneurs. Similarly, external discouraging factor is not a significant factor, i.e., no significant difference between students who are discouraged and non-discouraged by external factor on their self-employment intention.

Furthermore, creativity and problem solving skills are also among the most important determinants of intention of self-employment among undergraduate university students. According to this research findings, students who have high level of creativity and problem solving skills are more likely to be self-employed $(\mathrm{OR}=1.421)$ than students who have low level of creativity and problem solving skills. This finding is also in line with other previous studies (Ismail et al., 2013; Okpara, 2007; Hamidi et al., 2008). These show that students who have high level of creativity and problem solving skills have the highest intention to be self-employed. The reason might be a student with innovative mindset is more likely to initiate business and sustain it through continuous improvement. It means they find innovative ways to solve problem. They always look for new and better ways to do things.

The other qualities of successful entrepreneur are self-confidence and risk taking commitment. Some studies have revealed that intention of self-employment increases if the individuals have high self-confidence and self-esteem (Ismail et al., 2013). Our findings are in agreement with this fact. Students who have high self-confidence and self-esteem are more likely $(\mathrm{OR}=1.516)$ to be self-employed than from less confident students. The researchers believe that self-confident students have the ability to overcome business problems and succeed in the business activity. Most entrepreneurs start business because they like to be their own boss so that they are responsible for their own decisions. If a person is afraid of uncertainties, then he/she cannot be an entrepreneur. Unlike gamblers, entrepreneurs are not high-risk takers; they calculate their risks before taking action and place themselves in situations involving moderate risk.

Furthermore, this research revealed that other factors such as networking and professional contact, goal setting to their future career, and access to finance 
could also account for differences among the students on their attitude and intention for self-employment. In analyzing the findings, this research found evidence that these factors have positive contribution to the self-employment intention of students. From the result of the study, a student who establishes relationship, professional contacts and networks with business person had higher probability $(\mathrm{OR}=1.503)$ of being self-employed than students who did not make any professional contacts and networks because an entrepreneur acts to develop and maintain business contacts by establishing good working relationship and uses deliberate strategies to influence others. The ability to establish and maintain positive relationship is crucial to the success of the students' business venture (Turkina, Assche, and Kali, 2016). Hence, social relationship among formal inter-governmental organization networks to informal networks such as friendships and family ties affect decision-making and business performance. The social network stimulates business growth by reducing transaction costs, creating business opportunity, and generating knowledge spillover. Moreover, a student who sets meaningful and challenging goals for him/her has more likely to be self-employed than student who did not set goals.

Finally, the result of the current study revealed that students' self-employment intention was significantly predicted by student's entrepreneurial attitudes. From the above discussion, it can be seen that the predictors of self-employment intention identified in this study have all been well established in the literatures. Therefore, lack of access to finance for startup, lack of appropriate education/ training, low level of creativity and problem solving ability, low level of information and opportunity seeking, lack of prior business exposure, lack of business-owned family, lack of confidence, and low level of professional contacts and networking, low level of achievement and instrumental readiness, and lack of goal setting for their future career are some of important barrier factors that act to start a business by the students. These predictors have positive relationship with self-employment intention. In conclusion, H1: higher level of attitudes towards entrepreneurship is associated with higher level of self-employment intention is supported. On the contrary, profession of parents, short-term systematic planning, discouragement by external factors, number of entrepreneurs in which students know, and business-owned colleagues do not have any significant impact on self-employment intentions.

\section{Conclusions}

The study found that entrepreneurial attitudes do have significant impact on students' self-employment intention. The results have conformed to the literatures. Choosing a career path can be one of the most important decisions people make in their lives. Doing what they enjoy and having a job they like will have a positive effect on their lives, and it will ensure success (Gibson, Harris, Mick, and Burkhalter, 2011). In the research, it has been shown that being an entrepreneur requires a certain attitude, commitment, and positive thinking. It also requires faith in personal abilities and skills. Based on the collected data, it seems that in general, regardless of respondents' sex, age, and field of study, this research has 
arrived a conclusion that students who sought information and opportunity, took entrepreneurship education/training, set future goals, developed ability and skills on creativity and problem solving have a positive attitude towards self-employment. In line to this, the government as well as the universities should design programs that facilitate entrepreneurship to change the mindset, attitude, and intention of those students who do not have an idea about entrepreneurship as a future career. Government should also build students' confidence to consider self-employment as their future career. Moreover, access to finance, professional contacts and networking with entrepreneurs, prior business experience, family background, and achievement and instrumental readiness also significantly predict the intention of self-employment. So, it is important to maintain and strengthen the cooperation and contacts between students, fund raisers, and entrepreneurs. In conclusion, the results of the research showed that entrepreneurial attitudes and entrepreneurship education/trainings significantly predict self-employment intention of students at 5\% level of significance. On the contrary, demographic factors and socio-economic factors are not significant predictors of students' self-employment intention. Therefore, $H 1$ and $H 2$ of the research hypothesis are supported while $H 3$ and H4 are not.

Although a lot has been done to achieve the research objectives, there were some limitations and shortcomings. First of all, this research was conducted to investigate the cross-sectional effect of entrepreneurial attitudes on students' self-employment intention. The research does not include the longitudinal effect of entrepreneurial attitudes on self-employment. But the perception and attitude of students may be changed through time. Therefore, future research should be conducted to investigate not only the cross-sectional effect of entrepreneurial attitudes but also the longitudinal effect of entrepreneurial attitudes on self-employment intention of students. Secondly, this research was not used as a comparative research design. Therefore, future research should be used this research design to see the difference of self-employment intention between students placed in private and public universities and engineering students with business students. Secondly, the research covers only students from three universities in Ethiopia. Thus, the selected students from these universities are not enough to generalize students' self-employment intention in Ethiopia in general. Since there are so many universities in Ethiopia, future research should be considered other more university students.

\section{Appendix}

\section{Bahir Dar University}

Bahir Dar Institute of Technology

Questionnaires

Dear participants,

This questionnaire is prepared to conduct a research on entrepreneurial motivation and self-employment intention. It will use your information to model the impact of entrepreneurial motivation on self-employment intention. Only the researcher will access the data, and all your personal data will be kept strictly confidential. To this end, we kindly request you to complete this questionnaire 
regarding self-employment intention. It may not take more than $15 \mathrm{~min}$ to complete.

Instruction:

a) This questioner consists of a number of brief statements. Read each statement carefully and decide which one describes you most accurately. Be honest with yourself!

b) Circle the answer that is closest to your personal way of thinking or being.

c) Some statements may be similar, but none is the same.

For all your cooperation and concern, I will like to express my deepest gratitude! Section "Introduction": personal details

1. Gender A. Male B. Female

2. Age A. Below 20 years B. 20-24 C. above 24

3. Marital status A. Single B. Married C. Others, specify

4. Ethnic group A. Amhara B. Oromo C. Tigrie D. Others, specify

5. Religion A. Orthodox B. Muslim C. Protestant D. Others, specify

6. Field of study
A. Civil engineering
B. Electrical engineering
C. Mechanical engineering
D. Others, specify-

7. The longest residing area
A. Urban
B. Rural

8. Parent/guardians highest education level
A. No education at all
B. Elementary
C. Secondary
D. College and above

9. Occupation/profession of parent/guardian
A. Agricultural
B. Governmental employ
C. Business area
D. Others, specify 
10. How would you describe your family economic status?
A. Rich
B. Medium
C. Poor

11. Have you ever taken any entrepreneurship course(s) or training(s)? A. Yes B. No

12. If your answer for question 11 is "Yes," would a further entrepreneurship education and/or training strengthen your decision to become an entrepreneur? A. Yes B. No

13. If your answer for question 11 is "Yes," have you built a network of entrepreneurship with like-minded people during the education/training program?

A. Yes B. No

14. Do you believe that entrepreneurship education and/or training will change an attitude of students to become an entrepreneur? A. Yes B. No

15. How many entrepreneurs do you know personally?
A. Not at all
B. Less than 2
C. 2 up to 4
D. Above 4

16. To what extent, your relationship has influenced your intention to become an entrepreneur?
A. Weak
B. Medium
C. Strong

17. Is there anyone in your family who is/was self-employed or is owner of his/her business activities currently or before? A. Yes B. No

18. Have you worked together with your family in any private business activity?
A. Yes
B. No

19. Do you have any relative/collogue who is the owner of his/her business activity?
A. Yes
B. No

20. Have you tried to start a business before? A. Yes B. No

21. Do you think socio-cultural impacts have had any effects on self-employment endeavors?
A. Yes
B. No 
22. Do you want to work the field/training you have studying? A. Yes B. No

23. Are you motivated to be a self-employed person? A. Yes B. NO

24. What are the reasons to enter into self-employment?
A. Greater independence
B. Increase personal income
C. To change standard living style
D. Just maintain income
E. To continue the legacy of family

25. What type of business service you planned to run?
A. Service
B. Construction
C. Trade
D. Manufacturing
E. Others, specify-

26. Do you have an access of capital to start a business? A. Yes B. No

27. If your answer for question 26 is "Yes," what will be the source of finance for your self-employment?
A. Family
B. Colleague
C. Micro-finance
D. Inheritance
E. Others

28. If you plan to start a new task or project, will you gather information before you start? A. Yes B. No

29. Do you like discovering creative and innovative ways of doing? A. Yes B. No

30. What is your level of capacity in discovering creative and innovative ways of doing business activities?
A. No capacity at all
B. Low capacity
C. Medium capacity
D. High capacity

31. Do you have a clear idea of what you will do in the future? A. Yes B. No

32. Are you risk taker? A. Yes B. No

33. If your answer is "Yes" for question 32, what is your level of capacity in carrying out risky tasks? 

A. No capacity at all
B. Low capacity
C. Medium capacity
D. High capacity

34. If you face difficult tasks in your path, how do you overcome the obstacles to reach at your goal?
A. I will quit and start to do something else.
B. I will try different ways of overcoming.
C. I will spend a lot of time looking for a solution.
D. I will contact professional and expertise to help me to accomplish my goals.
E. Others, specify

35. Which of the following factors influences your attitude to become entrepreneur?
A. Guest speaker at University
B. University education
C. Mentor
D. Entrepreneur(s) in the family
E. Identification of a business idea
F. Found partner to start a business
G. Other, please specify:

Section "Literature review": the following statements are the measurement of self-employment intention of respondents. Please read the following sentences carefully and circle the answer that is closest to your personal way of thinking or being. The choices are $1=$ strongly disagree $(\mathrm{SD}), 2=$ disagree $(\mathrm{DA}), 3=$ neutral $(\mathrm{N}), 4=$ agree $(\mathrm{A})$, and $5=$ strongly agree (SA).

1. I prefer to be an entrepreneur rather than to be an employee in a company. 12345

2. I prefer to be an entrepreneur in my expertise.

3. I will make every effort to start and run my own business.

12345

4. I have strong intention to start my own business after completing my study. 12345

5. I would rather be my own business boss than have a secure job.

6. I am delighted to face the challenges of creating a new business.

7. Being an entrepreneur implies more advantageous than disadvantage. 12345

8. A career as entrepreneur is attractive \& entails great satisfaction for me. 12345

9. I am determined to create a business venture in the future.

Section "Methods": the following statements are the measurement of attitudes about entrepreneurial behaviors. Please read the following sentences carefully and circle the answer that is closest to your personal way of thinking or being. The choices are 1 = strongly disagree (SD), 2 = disagree (DA), 3 = neutral $(\mathrm{N}), 4=$ agree $(\mathrm{A})$, and $5=$ strongly agree (SA). 
1. I am mentally mature to start my own business.

2. I have an access to capital to start to be an entrepreneur.

3. I have good social relation with others to be an entrepreneur.

4. I have leadership qualities and skills that are need to be an entrepreneur. 12345

5. I will do very well in difficult tasks relating to my job.

6. I will try hard to improve on past work performance.

12345

7. I will accept additional responsibilities in job assigned to me.

12345

8. If I am involved in any business project, I believe I can perform very well. 12345

9. When I deal with successful businessperson, I am being inspired to start business.

12345

10. To succeed in business it is important to work with others.

12345

11. I shall feel uncomfortable if I am not sure of the goal of my future business. 12345

12. I think that there is always a better way of doing things. 12345

13. It bothers me when business activities do not go in the right manner. 12345

14. I would rather found a company than to be a manager of an existing one. 12345

15. I can only make a lot of money if I am self-employed.

12345

16. I feel confident that I can succeed in any business activities.

12345

17. I will change my way of thinking if others oppose my point of view.

12345

18. When I am doing something difficult, I feel confident that I will succeed. 12345

19. I can persuade people to change their opinion through discussion. 12345

20. I like to think about the future. 12345

21. I think it is a waste of time to worry about what I should do with my life. 12345

22. If I know well what I want to do, I will achieve it well. 12345

23. I prefer to focus on short term planning. $\quad 12345$

24. I will plan an extensive task by breaking it down into smaller activities. 12345

25. Before doing something, I carefully weigh the chances of success and failure. 12345

26. I try to take in to consideration all the problems that may crop up. $\quad 12345$

27. I deal with problems when they arise, rather than wasting time. 12345

28. If one way of solving a problem does not work, I will look for another approach. $\quad 12345$

29. To start a business project, I will gather information beforehand. $\quad 12345$

30. At the time of work, I will seek the advice of people. 12345

31. I will look for a new business that no one has done. 12345

32. I will do what I have to do before circumstances force me to do. 12345

33. I like challenges and new opportunities. 12345

34. I prefer doing things that I do easily and with which I feel comfort. $\quad 12345$

35. I have a satisfactory level of opportunity recognition. 12345

36. I have a capacity to create new ideas. 12345

37. I will make every effort to solve problem. 12345

38. I have strong leadership and communication skills. 12345

39. I will engage in the development of new products and services. 12345

40. I will make networking and professional contacts before starting business. 12345

41. I prefer to implement new ideas than existing ones. 12345 


\section{Acknowledgements}

Bahir Dar Institute of Technology funded this research. The researchers would like to thank Bahir Dar Institute of Technology, University of Gondar and Debre Markos University for the permission to collect the required data.

\section{Funding}

We received funding for this manuscript from Bahir Dar Institute of Technology.

\section{Availability of data and materials}

Data and material are available at any time. There are no restrictions on the availability of data and materials.

\section{Authors' contributions}

MMA did the major tasks of the work. He designed, innovated, and developed the overall conceptual framework for the analysis and interpretation of the data for the work. SAZ revised it critically for important intellectual content. He concentrated in detail on the literature review and its ramifications. Both authors read and approved the final manuscript.

\section{Authors' information}

Mesfin Mulu Ayalew is a senior lecturer and researcher at Bahir Dar University, Bahir Dar Institute of Technology, since 2016. He obtained his Bachelor and Master of Science in Applied Statistics from University of Gondar and Addis Ababa University respectively.

Shumet Amare Zeleke is a senior lecturer and researcher at Bahir Dar University, College of Social Science, Department of Political Science and International Studies, since 2016. He obtained his Bachelor and Master of Art in Philosophy from Addis Ababa University.

\section{Ethics approval and consent to participate}

Not applicable

\section{Consent for publication}

Not applicable

\section{Competing interests}

The authors declare that they have no competing interests.

\section{Publisher's Note}

Springer Nature remains neutral with regard to jurisdictional claims in published maps and institutional affiliations.

\section{Author details}

'Department of Statistics, Bahir Dar Institute of Technology, Bahir Dar University, Bahir Dar, Ethiopia. ${ }^{2}$ Department of Political Science and International Studies, Bahir Dar University, Bahir Dar, Ethiopia.

Received: 24 November 2017 Accepted: 19 July 2018

Published online: 24 August 2018

\section{References}

Agresti, M (2007). An introduction to categorical data analysis, (2nd ed., ). New York: Wiley-Interscience.

Bjuggren, CM, Johansson, D, Stenkula, M. (2012). Using self-employment as proxy for entrepreneurship: some empirical caveats. International Journal of Entrepreneurship and Small Business, 17(3), 290-303.

Cochran, WG (1979). Sampling techniques, (3rd ed., ). New York: John Wiley \& Sons, Inc.

Crant, JM. (1996). The proactive personality scale as a predictor of entrepreneurial intentions. Journal of Small Business Management, 34(3), 42-49.

Davey, T, Plewa, C, Struwig, M. (2011). Entrepreneurship perceptions and career intentions of international student. Journal of Education and Training, 53(3), 335-352.

Dohse, D., \& Walter, S, (2012). Knowledge Context and Entrepreneurial Intentions among Students. Journal of Small Business Economics, Springer, 39(4), 877-895.

Douglas, EJ, \& Shepherd, AD. (2002). Self-employment as a career choice: attitudes, entrepreneurial intentions, and utility maximization. Entrepreneurship Theory and Practice, 26(3), 81-90.

Dugassa, T. (2012). Impact of entrepreneurship education on entrepreneurial intentions of business and engineering students in Ethiopia. African Journal of Economic and Management studies, 3(2), 258-277.

Fitzsimmons, JR, \& Douglass, EJ (2005). Entrepreneurial attitude and entrepreneurial intention: a cross-cultural study of potential entrepreneurs in India, China, Thiland and Austrialia. Wellesley: Babson-Kauffman Entrepreneurs Research Conference.

Gemechis, T. (2007). Attitude of students for entrepreneurship in Addis Ababa University and Reft Vally University. European Journal of Business and Management, 6(4), 350-363.

Gibson, SG, Harris, ML, Mick, TD, Burkhalter, TM. (2011). Comparing the entrepreneurial attitudes of university and community college students. Journal of Higher Education Theory and Practice, 11(2), 1-8

Hamidi, D, Wennberg, D, Berglund, H. (2008). Creativity in entrepreneurship education. Journal of Small Business and Enterprise Development, 15(2), 304-320.

Hilbe, S (2009). Logistic regression model. New York: Chapman and hall/ CRC.

Hosmer, A, \& Lemeshow, M (2000). Applied logistic regression, (2nd ed., ). Chicago: Wilry publisher.

Inegbenobor, U. (2006). Equity investment in small scale businesses. Journal of Business and Management, 15(4), 345-356. 
Ismail, N, Jaffar, N, Hooi, TS. (2013). Using EAO model to predict the self-employment intentions among the universities' undergraduates in Malaysia. International Journal of Trade, Economics and Finance, 4(5), 90-97.

Kristiansen, S, \& Indarti, N. (2004). Entrepreneurial intention among Indonesian and Norwegian students. Journal of Enterprising Culture, 12(1), 55-78.

McStay, D (2008). An investigation of undergraduate student self-employment intention and the impact of entrepreneurship education and previous entrepreneurial experience: school of business. Australia: Bond University.

Meyers, LS, Gamst, G, Guarino, AJ (2006). Applied multivariate research: design and interpretation. Thousands: Sage.

Moreno, J, Castillo, L, Triguero, M. (2012). The effect of business and economics education programs on students' entrepreneurial intention. European Journal of Training and Development, 36(4), 409-425.

Nguyen, C. (2017). Entrepreneurial intention of international business students in Viet Nam: a survey of the country joining the Trans-Pacific. Journal of Innovation and Entrepreneurship, 6(7), 1-13

Nishantha, B (2008). Influence of personality traits and socio-demographic background of undergraduate students on motivation for entrepreneurial career: the case of Sri Lanka. Kyoto: Doshisha Business School.

Okpara, FO. (2007). The value of creativity and innovation in entrepreneurship. Journal of Asia Entrepreneurship and Sustainability, 3(2), 1-14

Olufunso, OF. (2010). Graduate entrepreneurial intention in South Africa: motivation and obstacles. International Journal of Business and Management, 5(9), 87-98.

Osakede,UA, Lawanson, AO, Sobowale, DA. (2017) Entrepreneurial interest and academic performance in Nigeria: evidence from undergraduate students in the University of Ibadan. Journal of Innovation and Entrepreneurship, 6 (19), 1-15.

Plant, R, \& Ren, J. (2010). A comparative study of motivation and entrepreneurial intentionality: Chinese and American perspectives. Journal of Developmental Entrepreneurship, 15(2), 187-204.

Rietveld, CA, Hessels, J, Zwan, P. (2014). The stature of the self-employed and its premium. Tinbergen Institute Discussion Paper, 11(109), 1-18.

Robinson, BP, Stimpson, DV, Heufner, JS, Hunt, K. (1991). An attitude approach to the prediction of entrepreneurship. Entrepreneurship Theory and Practice, 15(4), 13-31.

Robson, M. (2015). Determining entrepreneurial motivation of undergraduate student in Ethiopia higher learning institutions: the case of Haramaya University. Middle Eastern \& African Journal of Educational Research, 14(4), 214-225.

Sanditov, B, \& Verspagen, B. (2011). Multilevel analysis of the determinants of innovative entrepreneurship across Europe. Maastricht University. Paper presented at the Final DIME Conference, 4(2), 6-8.

Schaumburg-Müller H., Jeppesen, S. \& Langevang, T. (2010). Entrepreneurship development in Africa: report from a workshop. Working Paper Series.

Serneels, P. (2004). The nature of unemployment in urban Ethiopia. The working paper Centre for the Study of African Economics (CSAE).

Shariff, MN, Saud, MB. (2008). An attitude approach to the prediction of entrepreneurship on students at institution of higher learning in Malaysia. International Journal of Business and Management, 4(4), 129-135.

Taatila, V. (2010). Learning entrepreneurship higher education. Journal of education and Training, 5(2), 48-61.

Tseng, C. (2013). Connecting self-directed learning with entrepreneurial learning to entrepreneurial performance. International Journal of Entrepreneurial Behavior and Research, 19(4), 425-446.

Turkina, E, Assche, AE, Kali, R. (2016). Structure and evolution of global cluster networks: evidence from the aerospace industry. Journal of Economic Geography, 16(6), 1211-1234.

Ummah, S. (2009). Entrepreneurial motivation and self-employment intention: an empirical study on management undergraduates in Sri Lanka. Journal of Management, 5(1), 87-96.

Wu, S, \& Wu, L. (2008). The impact of higher education on entrepreneurial intentions of university students in China. Journal of Small Business and Enterprise Development, 15(4), 752-774.

Yamane, T (1967). Statistics: an introductory analysis, (2nd ed., ). New York: Harper and Row.

Zain, MZ, Akram, MA, Ghani, EK. (2010). Entrepreneurship intention among Malaysian business students. Canadian Social Science, 6(3), 34-44.

Zampetakis, L, Kafetsios, K, Bouranta, N, Dewett, T, Moustakis, V. (2009). On the relationship between emotional intelligence and entrepreneurial attitudes and intentions. International Journal of Entrepreneurial Behavior and Research, 15(6), 595-618.

Zhang, P, Wang, DD, Owen, CL. (2015). A study of entrepreneurial intention of university students. Entrepreneurship Research Journal, 5(1), 61-82.

Zhao, H, Hills, GE, Seibert, S. (2005). The mediating role of self-efficacy in the development of entrepreneurial intentions. Journal of Applied Psychology, 90(6), 1265-1272. 